\title{
TYÖELÄMÄN MUUTOKSET JA AIKUISKOULUTUS
}

\begin{abstract}
Työmarkkinat näyttävät mitä ilmeisimmin lohkoutuvan sekä työtehtävien ettå koulutuksen osalta. Keskeisimmin aikuiskoulutustarpeiden laajenemiseen vaikuttaa työtehtävien vaatimustason nousun. Työtehtävien kehitys sekä ammatilliset täydennys- ja jatkokoulutustarpeet kasautuvat kuitenkin jo ennestään koulutetuille ryhmille. Koulutukseen osallistumista estäviksi tekijöiksi puolestaan koetaan taloudelliset ja ajalliset rajoitukset, kirjoittaa Hely Salmela artikkelissaan.
\end{abstract}

\section{Ammatillisen \\ aikuiskoulutuksen nousu}

Yhteiskunnallisen rakennemuutoksen uskotaan vaikuttavan ihmisiin voimakkaimmin työssä tapahtuvien muutosten kautta. Työelämän tekniset muutokset heijastuvat myös ammatti- ja työpaikkarakenteeseen. Keskeiseksi ongelmaksi on muodostumassa työvoiman kysynnän ja tarjonnan yhteensovittaminen, missä yhteensovittamisen keinona nähdään juuri koulutus. Työelämässä ammatinvaihto jopa montakin kertaa työuran aikana on jo yleistä. Koulutuksen avulla pyritään lisäämään väestön ammatillista ja alueellista liikkuvuutta.

Olemme siirtymässä sukupolvien välisestä uusintamisesta sukupolvien sisäiseen uusinta. miseen, jossa elinikäisellä koulutuksella on yhä keskeisempi asema.

Työelämän kehityksen nähdään vaikuttavan voimakkaasti erityisesti ammatilliseen koulutukseen. Tämä tulee esille myös valtioneuvoston vuonna 1988 tekemässä ammatillisen aikuiskoulutuksen kehittämistä koskevassa pää. töksessä. Koulutukselta vaaditaan aiempaa parempaa mukautumista työelämän tarpeisiin. (VNP 1988.) Koulutusjärjestelmän kehitys kytkeytyy työvoimaa kvalifioivana ja valikoivana systeeminä kiinteästi yhteiskunnan yleiseen muutokseen. Aikuiskoulutuksen kehittämistä pidetään paitsi yhteiskunnallisten muutosten aikaansaamana myös välttämättömänä koko koulutusjärjestelmän toimivuuden kannalta. 1960-luvulla yhteiskuntapolitiikan yhdeksi keskeiseksi tehtäväksi nousi aikuiskoulutuksen kehittäminen. Aikuiskoulutuksen aseman korostus näkyy myös valtiollisen tason koulu. tussuunnittelussa. 1970- ja 1980-luvuilla on tehty useita aikuiskoulutuksen tilaa ja tarvetta sekä aikuiskoulutukseen osallistumista käsitteleviä tutkimuksia. Samalla alueellinen kiinnostus aikuiskoulutuksen kehittämiseen on ollut vankassa kasvussa.

Uudessakaupungissakin, jota käytän artikkelini empiirisenä esimerkkinä, lähdettiin vuonna 1988 kartoittamaan aikuisten amma. tillisen koulutuksen tarvetta. Saatujen tulosten avulla pyritään yhtenäistämään ja kehittämään alueen ammatillista aikuiskoulutusorganisaa. tiota. Artikkelini tarkoituksena on selvittää aikuisten ammatillisen koulutuksen tarvetta esimerkkinä Uusikaupunki - sekä pohtia koulutustarpeiden laajenemisen yhteyksiä yhteiskunnallisiin tekijöihin. Alueen ammatillisen aikuiskoulutuksen tarpeita ja taustoja selvitetään kyselemällä uusikaupunkilaisen työikäisen väestön (15-64 -vuotiaiden) koulutustarpeita sekä vertailemalla niitä Uudessakaupungissa toimivien työnantajien esittämiin henkilöstökoulutustarpeisiin.

Väestöotokseen tuli vajaat 2000 henkilöä (viidennes perusjoukosta) ja vastausprosentti oli 60 . Työnantajien henkilöstökoulutustarpeet selvitettiin kyselyin ja haastatteluin. Tutkimukseen otettiin mukaan kaikki vähintään 30 henkilöä työllistävät työnantajat ja muista työnantajista otos toimialoittain. Otokseen tuli 65 toi- 
mipaikkaa (15 prosenttia perusjoukosta) ja vastausprosentti oli noin 80 .

Seuraavassa esitellään päätulokset ja arvioidaan koulutustarpeiden yhteiskunnallisia syitä ja seurauksia.

\section{Nykyinen koulutus ja työtehtävien kehitys}

Työnantajien arvioiden mukaan noin neljäsosalla henkilökunnasta oli puutteellinen koulutus. Erityisesti työntekijöiden ja työnjohtajien koulutustaso oli liian alhainen tai ei vastannut työn sisältöä. Väestökyselynkin mukaan puut- teellinen koulutus oli noin neljänneksen huo. lena. Joka kymmenes oli sitä vastoin tehtä. viinsä nähden ylikoulutettu. Koulutustason mataluus oli erityisesti yli 35-vuotiaiden ongelma, nuoret palkansaajat puolestaan olivat koulutustasoonsa nähden liian vaatimattomas. sa työssä.

Tulevaisuudessa uskottiin työtehtävien kvalifikaatiovaatimusten nousevan ja koulutetun henkilökunnan tarpeen kasvavan. Näkemykset vaihtelivat kuitenkin melko lailla sukupuolen, ikäryhmien, eri tavoin koulutettujen ja eri työasemissa olevien välillä. Seuraavaan on koottu tulosten perusteella karkea yleiskatsaus työn tulevaisuudennäkymistä.

\begin{tabular}{|c|c|c|c|c|c|c|c|c|}
\hline \multirow{3}{*}{$\begin{array}{l}\text { Aikuiskoulutus- } \\
\text { muodot }\end{array}$} & \multicolumn{8}{|c|}{ Henkilöstöryhmät } \\
\hline & \multicolumn{2}{|c|}{$\begin{array}{l}\text { Johtavat } \\
\text { toimihen- } \\
\text { kilöt }\end{array}$} & \multicolumn{2}{|c|}{$\begin{array}{l}\text { Muut } \\
\text { toimihen- } \\
\text { kilöt }\end{array}$} & \multicolumn{2}{|c|}{$\begin{array}{l}\text { Työn- } \\
\text { johtajat }\end{array}$} & \multicolumn{2}{|l|}{$\begin{array}{l}\text { Työn- } \\
\text { tekijät }\end{array}$} \\
\hline & $\mathrm{T}$ & V & $\mathrm{T}$ & v & $\mathrm{T}$ & v & $\mathrm{T}$ & V \\
\hline $\begin{array}{l}\text { Ammatillinen } \\
\text { peruskoulutus }\end{array}$ & $4 \%$ & $9 \%$ & $8 \%$ & $8 \%$ & $12 \%$ & $2 \%$ & $14 \%$ & $10 \%$ \\
\hline $\begin{array}{l}\text { Ammatillinen } \\
\text { täydennys- } \\
\text { koulutus }\end{array}$ & $63 \%$ & $72 \%$ & $68 \%$ & $76 \%$ & $52 \%$ & $84 \%$ & $56 \%$ & $68 \%$ \\
\hline $\begin{array}{l}\text { Ammatillinen } \\
\text { jatkokoulutus }\end{array}$ & $33 \%$ & $19 \%$ & $24 \%$ & $15 \%$ & $36 \%$ & $14 \%$ & $30 \%$ & $22 \%$ \\
\hline Yhteensä & $100 \%$ & $100 \%$ & $100 \%$ & $100 \%$ & $100 \%$ & $100 \%$ & $100 \%$ & $100 \%$ \\
\hline
\end{tabular}

Taulukko 1. Ammatillisen lisäkoulutuksen tarve henkilöstöryhmittäin työnantaja• ja väestökyselyn mukaan ( $T$ = työnantajakysely, $V=$ väestökysely)

Keskeisinä työvoiman erottelijoina pidetään mm. koulutusta, sukupuolta ja ikää (esim. Nätti 1989). Koulutus määrittää ihmisen ase. man työmarkkinoilla. Koulutuksen voidaan olettaa vaikuttavan myös miesten ja naisten käsityseroihin työn kehittymisestä. Yli 40-vuotiaiden ikäryhmässä miesten koulutustaso on melko selvästi naisten koulutusta korkeampi ja koko väestöstä miehet ovat suoritta. neet tutkintoja keskimäärin enemmän kuin naiset.

Naisten ja miesten asemaan työmarkkinoilla vaikuttaa myös se, miten työnjako perheen sisällä on järjestetty. Urakehitys edellyttää yleensä jatkuvaa ja kokoaikaista työssäkäyntiä.
Perinteiset käsitykset perheenjäsenten rooleista ovat vaikuttaneet koulutusvalintoihin. Per. heen pääasiallinen tulonhankkija on tavallisesti ollut mies, nainen on hankkimassa työstä vain lisätuloja. Nuoremmissa ikäryhmissä korkea koulutustaso ei enää ole miesten etuoikeus: alle 30-vuotiaiden ikäryhmässä naiset ovat koulutustasoltaan ohittaneet miehet.

Yleisen koulutustason nousun myötä suku. puoli ei enää vaikuta yhtä voimakkaasti myöskään näkemyksiin työn kehityksestä. Koulutusvaatimusten asema työelämään rekrytoinnissa näyttää entisestään korostuneen.

Eri ammattialoilla työskentelevien ihmisten näkemyserot työtehtävien kehityksestä ovat 
yhteneväisiä eri ammattiryhmien koulutustaustaerojen kanssa.

Tutkimuksen mukaan myönteisin käsitys oman työn kehittymisestä oli parhaiten koulutetuilla aloilla työskentelevillä. Korkein koulutustaso oli palvelusektorien ihmisillä, jotka myös näkivät työnsä kehityksen myönteisenä. Teollisuuden ja kuljetusalan ammateissa työskentelevät puolestaan näkivät työnsä tulevaisuuden pessimistisimpänä. Nämä alat kuuluvat myös koulutustasoltaan heikoimpiin, sillä lähes 45 prosenttia työvoimasta oli vailla am. matillista koulutusta. Toisaalta tutkimus antoi aihetta olettaa, että teollisuudessa on tapahtumassa voimakasta teknisestä kehityksestä juontuvaa työtehtävien vaatimustason nousua. Tämän kehityksen nähtiin koituvan kuitenkin vain harvojen osalle: pienen osan työtehtävät vaativat yhä enemmän ammattitaitoa, suurin osa tulee toimeen vähällä koulutuksella (vrt. Takala 1984; Lehtisalo \& Raivola 1986).

Tuloksia voidaan selittää työmarkkinoiden ns. lohkoutumisesta käsin. Lohkoutumisteoriossahan lähdetään usein liikkeelle siitä, että työ on jakautumassa primääri- ja sekundäärisegmentteihin. Primäärisegmentillä työolosuhteet, palkat ja urallaetenemismahdollisuu. det ovat sekundäärilohkoa paremmat. Primäärisegmentillä työskentelevät pitkälle koulutetut, hyväosaiset ihmiset.

Sekundäärityömarkkinoilla toimii puolestaan elämänperspektiivinään matalan statuksen omaavia henkilöitä $\mathrm{mm}$. nuoria, ikääntyneitä ja naisia. Myös koulutusmahdollisuudet ja koulutuksen vaikutus oman taloudellisen sekä sosiaalisen aseman parantamiseen on riippuvainen aikaisemmin saavutetusta asemasta yhteiskunnassa ja työmarkkinoilla, siis työmarkkinasegmenteistä. (ks. Kivinen $\mathcal{E}$ Rin. ne 1989, 62 - 68; Nätti 1989, 33 - 39.)

Koulutusta voidaan tarkastella paitsi työtehtävien kehittymisen aikaansaamana, myös eri intressiristiritojen pohjalta, jossa koulutustarpeet kytketään yhteiskunnallisten ryhmien, esimerkiksi ammattiryhmien väliseen kilpailuun työmarkkinoilla. Koulutuksellisen vaatimustason korostamisen avulla vahvistetaan myös sosiaalista asemaa. Konfiktiteoreetikko Randall Collinsin mielestä koulutuksella onkin jopa enemmän merkitystä ammattistatuksen luomisessa ja valikoinnissa kuin ammattitaitojen hankkimisessa. (Collins 1971, 1001, 1009.1013; Collins 1979 16, 21, 31.32.)

\section{Koulutustarpeiden tausta}

Elinkeino- ja ammattirakenteen kehittymisessä oli Uudellekaupungille ominaista voima. kas teollisuus, laajenevat palvelualat sekä muuttuvat työtehtävät. Tämä nopea kehitys näyttää aiheuttavan epätasapainoa työvoiman kysynnän ja tarjonnan välille. Työnantaja- ja väestötutkimuksen tulosten perusteella ammatillisten aikuiskoulutustarpeiden synty ja laajeneminen liitetään pääosin teknisen ja muun yhteiskunnallisen kehityksen aikaansaamaan työtehtävien kvalifikaatiovaatimusten nousuun. Koulutustarpeiden laajenemista perustellaan lähinnä teknologisen kehityksen aikaansaamina koulutusvaatimuksina, minkä katsotaan ohjaavan koulutustarpeet tietyille ammattiryhmille.

Työtehtävät näyttävät kehittyvän laaja-alaisemmiksi, mutta myös työtehtävien erikoistumista oletettiin tapahtuvan erityisesti alle 20 henkilöä työllistävissä toimipaikoissa.

Yli 35-vuotiaiden koulutustaso oli selvästi matalampi kuin nuorilla. Tämä yhdessä elinkeino- ja ammattirakenteessa tapahtuvien muutosten ja työtehtävien teknisen kehityksen kanssa lisää ammatillisen aikuiskoulutuksen tarvetta. Voimakkaimmin työelämässä tapahtuvat muutokset koskettavat juuri niitä amma. tissa toimivia aikuisia, joiden koulutustaso osoittautui heikoksi.

Uudenkaupungin väestön ikärakenteessa nuorten ja työikäisten osuus oli keskimääräistä suurempi. Väestö on kuitenkin hitaasti vanhenemassa, mitä ei voine estää edes tähän asti suotuisa muuttoliike.

\section{Koulutuksen kasautuminen}

Innostus aikuiskoulutukseen oli varsin vilkasta. Yli 4/5 vastanneista oli osallistunut johonkin aikuiskoulutukseen.

Tulokset osoittavat kuitenkin sosiaalisen aseman ja koulutustaustan vaikuttavan koulutukseen osallistumiseen ja koulutustarpeiden kokemiseen. Osallistumisaktiivisuus näyttää nousseen 1980-luvun alun määrästä (vrt. Haven $\mathcal{E}$ Syvänperä 1983). Myös sukupuolten väliset erot "ilmenneissä" koulutustarpeissa eli aikuiskoulutukseen osallistumisessa ovat tasoittumassa, kuten jo 1970- ja 1980-luvun tutkimukset antavat olettaa (ks. Lehtonen $\mathcal{E}$ Tuomisto 1973; Haven E Syvänperä 1983). Naiset osallistuivat kuitenkin edelleen miehiä aktiivisemmin kansalais- ja työväenopistojen kursseille.

"Koettu" koulutustarve näyttää kasautuvan sosiaalisen aseman mukaan johtaville toimihenkilöille ja palvelualoilla työskenteleville. Koulutuksen sosiaalisesta kasautumisesta 
huolimatta iän vaikutus ainakin "koettuihin" koulutustarpeisiin näyttää olevan edelleen vähenemässä, sillä koulutustarpeiden koettiin vähenevän huomattavasti vasta 54 ikävuoden jälkeen. Suunta on siis ollut sama kuin Havenin E Syvänperän 1980-luvun alun tutkimuksessa.

Koulutuksellinen tasa-arvo ei näytä juurikaan lisääntyneen eri sosiaaliryhmien välillä 1970- ja 1980-lukujen aikana, sillä jo 1970-luvun alussa Lehtonen $\mathcal{E}$ Tuomisto (1973) päätyivät saman suuntaisiin tuloksiin. Tasoittumista on tapahtunut kuitenkin suku. puolten ja eri ikäryhmien koulutustarpeiden ja koulutukseen osallistumisen välillä koulutustarpeiden yleisen laajenemisen ja osallistumisaktiivisuuden kasvun myötä.

Työnantajat keskittivät koulutuksen toimihenkilöryhmille (erityisesti johtaville toimihenkilöille), vaikka suurimpien puutteiden koulutuksessa katsottiin olevan työntekijöillä. Teollisuuden koulutusvaliokunnan vuonna 1984 tekemän tutkimuksen mukaan erot toimihenkilöiden ja työntekijöiden koulutusmäärissä olivat pienemmät kuin Uudessakaupungissa (vrt. Teollisuuden koulutus 1984). Ero johtunee siitä, että tässä tutkimuksessa oli suhteellisesti enemmän mukana pieniä, vähemmän henkilöstökoulutusta järjestäviä toimipaikkoja.

Yrityskoko vaikuttaa selvästi koulutustoiminnan laajuuteen ja koulutuskustannuksiin. Molempien tutkimusten mukaan työnantajat näyttivät suhtautuvan ammatillisen aikuiskoulutuksen laajentamiseen ja vaikuttavuuteen myönteisesti. Nuorten koulutusta ei katsottu tarpeelliseksi lisätä, vaan voimavaroilla tulisi kehittää lisäkoulutusta.

\section{Ammatilliset lisäkoulutustarpeet}

Aikuiskoulutustarpeet liittyivät tutkimuksen mukaan erityisesti ammattitaidon ylläpitoon tähtäävään täydennyskoulutukseen. Tämä korostui sekä työnantaja. että väestökyselyn tu. loksissa kaikissa henkilöstöryhmissä.

Väestökyselyssä eniten koulutustarpeita kokivat johtavassa asemassa olevat toimihenkilöt ja 25-54 -vuotiaat. Vähiten koulutuksen tar. peessa puolestaan ilmoittivat olevansa yli 55-vuotiaat ja työntekijät. Täydennyskoulutus. ta tarvitsisivat tutkimuksen mukaan kaikki henkilöstöryhmät, jatkokoulutustarpeita arvioitiin olevan eniten työnjohtajilla sekä johtavilla toimihenkilöillä. Silti lähes joka kolmas työnantaja katsoi työntekijöidensä tarvitsevan jatkokoulutusta. Peruskoulutustarpeita oli selvästi vähiten. Teollisuuden ja palvelualojen voimak. kuus Uudessakaupungissa vaikutti myös koulutustarpeiden keskittymiseen näille aloille.

Tulosten perusteella työnantajien ja palkansaajien intressit koulutustarpeissa näyttävät Uudessakaupungissa pääpiirteiltään yllättävän yhteneväisiltä. Työnantajien koulutustoiminta sekä arviot koulutustarpeista keskittyivät toimihenkilöryhmiin, jotka myös henkilöstöryhmistä useimmin ilmoittivat tarvitsevansa lisä. koulutusta. Molempien intressiryhmien etujen mukaista olisi keskittyä erityisesti ammatilli. seen täydennyskoulukseen. Ammatilliset perus- ja jatkokoulutustarpeet tulivat esille työnantajien koulutustarvearvioissa korostuneemmin kuin väestön kokemissa koulutustarpeissa, joissa puolestaan täydennyskoulutustarpeet painottuivat. Ainekohtaisista koulutustar. peista keskeisimmiksi nousivat ihmissuhde- ja ATK-koulutus.

\begin{tabular}{|c|c|c|}
\hline $\begin{array}{l}\text { Työ kehittyy vaativammaksi } \\
\text { ja monipuolisemmaksi }\end{array}$ & $\begin{array}{l}\text { Työ pysyy samanlaisena tai } \\
\text { muuttuu yksitoikkoisemmaksi }\end{array}$ & $\begin{array}{l}\text { Työtehtävät muuttuvat toisilla } \\
\text { mielenkiintoisemmiksi ja toi- } \\
\text { silla taas yksitoikkoistuvat tai } \\
\text { pysyvät ennallaan }\end{array}$ \\
\hline $\begin{array}{l}\text { - miehillä } \\
\text { - hyvin koulutetuilla ja kou- } \\
\text { lutustaan vastaavassa } \\
\text { työssä olevilla } \\
\text { - opetus-, terveydenhuol- } \\
\text { to- sekä julkisen alan am- } \\
\text { mateissa }\end{array}$ & $\begin{array}{l}\text { - naisilla } \\
\text { - } \text { matalan koulutuksen } \\
\text { saaneilla ja koulutustaan } \\
\text { vastaamattomassa työs- } \\
\text { sä olevilla } \\
\text { - teollisuuden ja kuljetusa- } \\
\text { lan ammateissa }\end{array}$ & $\begin{array}{l}\text { - alle 35-vuotiaiden ryh- } \\
\text { mässä } \\
\text { — teollisuuden ammateissa }\end{array}$ \\
\hline
\end{tabular}


Taulukko kertoo paitsi täydennyskoulutustarpeen korostuneen aseman, myös sen, että työnantajat painottivat erityisesti jatkokoulutustarpeita, väestö taas täydennyskoulutustarpeita. Työnantajat näyttävät näin kiinnittävän huomiota erityisesti tulevaisuuden koulutusvaatimuksiin.

Työnantajien kannalta henkilökunnan koulutustarve ei ilmene vain tietyn tehtävän opettamisena, vaan siihen liittyy myös pyrkimys lisätä tulevaisuudessa henkilökunnan joustavaa liikuteltavuutta työtehtävistä ja asemista toisiin.

Palkansaajien arvioissa täydennyskoulutustarpeiden voimakas korostuminen viitannee siihen, että suurin osa vastanneista arvioi koulutustarpeensa pääasiassa sen hetkisten työtehtävien mukaan.

Kvalifikaatioiden sisältöjen ja soveltamismahdollisuuksien katsotaan vaikuttavan siihen, miten työnantajat haluavat itse huolehtia yrityskohtaisia erityiskvalifikaatioita tarvitsevan henkilökunnan koulutuksesta ja antaa yleiskvalifikaatioiden tuottaminen julkisen vallan tehtäväksi, jolloin säästetään koulutus- ja palkkauskustannuksissa (Becker 1975, 19.26; Tuomisto 1986, 47). Työnantajien mielestä toimihenkilöille sopivin koulutusmuoto oli $\mathrm{Uu}$ dessakaupungissa toimipaikan sisäinen koulutustoiminta, työntekijöiden koulutus puolestaan tulisi hoitaa ammatillisissa oppilaitoksissa ja kurssikeskuksissa eli yhteiskunnan omista. missa oppilaitoksissa.

\section{Koulutusmotiivit ja esteet}

Palkansaajien pääasiallinen koulutusmotiivi oli kvalifikaatiotason nostaminen siten, että pysyttäisiin kehityksen tasalla, parannettaisiin palkkatasoa ja edettäisiin uralla. Koulutukseen

\section{LÄHTEET}

Becker, G.S. 1975. Human capital. A theoretical anc' empirical analysis, with special reference to education. New York and London: Columbia University press.

Collins, R. 1971. Functional and conflict theories of educational stratification. American sosiological review 36, $1001-1019$.

Collins, R. 1979. The credential society. London: Allen \& Unwin.

Haven, H. \& Syvänperä, R. 1983. Aikuiskoulutukseen osallistuminen 1980. Tilastokeskuksen tutkimuksia 92. Tilastokeskus. Helsinki.

Kivinen, O. \& Rinne, R. 1989. Koulutuksen kentät ja kulku. Teoksessa T. Takala (toim.) Kasvatussosiologian perusteet. Jyväskylän yliopiston täydennyskoulutuskeskus. Oppimateriaaleja 2, 57-98.

Lehtisalo, L. \& Raivola, R. 1986. Koulutuspolitiikka ja koulutussuunnittelu. Juva: WSOY. osallistumisen kannalta tärkeää näytti olevan se, kuinka paljon yksilö kokee koulutuksen vaikuttavan asemaansa työmarkkinoilla. Koulutus nähtiin välineenä tiettyjen päämäärien saavuttamiseksi. Koulutusesteistä keskeisimmiksi nousivat olosuhde-esteet, joista vaikeimmiksi koettiin taloudelliset esteet sekä ajan ja koulutusmahdollisuuksien puutteen aiheuttamat vaikeudet. Naiset valittivat lastenhoitohankaluuksia ja lähellä olevien koulutusmahdollisuuksien puutetta. Miesten ajan sen sijaan veivät muut harrastukset, ja heillä oli myös huonoja kokemuksia opiskelusta. Esteet ovat siis edelleen samanlaisia kuin 1970-luvulla (vrt. Lehtonen $\mathcal{E}$ Tuomisto 1973).

Työnantajien huolet olivat toisaalla. He kokivat koulutustoimintaa eniten vaikeuttaviksi tekijöiksi työajan menetykset ja korkeat koulutuskustannukset.

\section{Johtopäätöksiä}

Työmarkkinat lohkoutuvat mitä ilmeisim. min sekä työtehtävien että koulutuksen osalla. Työtehtävien kvalifikaatiovaatimusten nousu ja tähän kytkeytyvä koulutustarve näyttää kasau. tuvan jo ennestään koulutetuille. Eniten lisäkoulutusta katsovat tarvitsevansa hyvin koulu. tetut henkilöt samalla kun työnantajien koulutustoiminta keskittyy samoille henkilöstöryh. mille.

Eri työtehtävien kvalifikaatiovaatimusten epätasainen kehitys ja työtehtävien osittainen polarisoituminen ohjaavat teknisten ja yhteiskunnallisten muutosten aiheuttamia koulutustarpeita. Kredentialistinen "koulutuspolitiikka" vaikuttaa kuitenkin virallisten tavoitteiden taus. talla. Kasautumis- ja polarisoitumiskehityksen voidaan nähdä jatkossakin tukevan kilpailuasetelman säilymistä eri työelämän intressiryhmien välillä.

Lehtonen, H. \& Tuomisto, J. 1973. Aikuiskoulutus Suomessa: käsitykset ja käyttö. Tampereen yliopisto. Yhteiskuntatieteiden tutkimuslaitos. A-tutkimuksia no. 45. Tampere.

Nätti, J. (1989) Työmarkkinoiden lohkoutuminen. Segmentaatio-teoriat, Suomen työmarkkinat ja yritysten työvoimastrategiat. Jyväskylä studies in education, psychology and social research 68. Jyväskylän yliopisto. Jyväskylä.

Takala, T. 1984. Koulutukseen tulevaisuudessa kohdistuvat vaatimukset - koulutussosiologisia näkökulmia. Aikuiskasvatus 4, 3, $126-129$.

Teollisuuden koulutus 1984. 1986. Teollisuuden koulutusvaliokunta. (STK \& TKL). A-sarja. Helsinki.

Tuomisto, J. 1986. Teollisuuden koulutustehtävien kehittyminen. Tutkimus teollisuustyönantajien koulutustoiminnan ja kvalifikaatiointressien historiallisesta kehityksestä Suomessa. Acia Universitasis Tamperensis. Ser A vol 209. Tampereen yliopisto. Tampere. 
Salmela Hely 1991. Työelämän muutokset ja aikuiskoulutus.

- Artikkelissa käsitellään aikuiskoulutustarpeita, niiden taustoja ja seurauksia yksilöiden ja työorganisaatioiden näkökulmasta.

Työmarkkinat näyttävät lohkoutuvan sekä työtehtävien että koulutuksen osalta. Keskeisimmin aikuiskoulutustarpeiden laajenemiseen näyttää vaikuttavan työtehtävien vaatimustason nousu. Työtehtävien kehitys sekä ammatilliset täydennys- ja jatkokoulutustarpeet kasautuvat kuitenkin koulutetuille ryhmille. Koulutukseen osallistumista estäviksi tekijöiksi koetaan taloudelliset ja ajalliset rajoitukset.

Aikuiskasvatus 11,1.
Salmela Hely 1991. Changes in the working life and adult education.

- The article deals with adult education needs, their backgrounds and consequences from the point of view of individuals and worklife organisations. It seems that the labour market is becoming segmented with respect to both work tasks and training. The most significant factor working towards the expansion of adult education needs appears to be the rise in the demand level of work tasks. Nevertheless, development in work tasks and vocational further and in-service training needs accumulate for trained personnel groups. Factors preventing participation in training are felt to be economic and availability of time limitations.

Aikuiskasvatus 11,1. 